\title{
Directing our own careers, but getting help from empowering leaders
}

\author{
Minseo Kim and Terry A. Beehr \\ Department of Psychology \\ 233 Sloan Hall \\ Central Michigan University \\ Mount Pleasant, Michigan 48859, U.S.A.
}

Some of these data were presented at the $32^{\text {nd }}$ annual meeting of the Society for Industrial and Organizational Psychology, Orlando, FL.

About the authors

Minseo Kim is an I/O Psychology PhD Student at the Central Michigan University. Her research interests include occupational stress, leadership, motivation, careers, and employee well-being. Minseo Kim is the corresponding author and can be contacted at: minseokim0331@gmail.com

Terry A. Beehr is a Professor of Psychology and Member of the I/O Psychology Faculty at the Central Michigan University. His research interests include occupational stress, retirement, leadership, motivation, and careers. 


\begin{abstract}
Purpose - This study examined the potential effects of empowering leadership on followers' subjective career success through psychological empowerment, protean career orientation, and career commitment.
\end{abstract}

Design/methodology/approach - Full-time employees working in the United States were recruited through Amazon's Mechanical Turk. Participants answered surveys at three separate points over a six-week period $(n=261)$. Structural equation modeling and bootstrapping were used to verify the indirect effect of empowering leadership on career satisfaction controlling for common method variance and growth need strength.

Findings - Empowering leadership was positively related to followers' subsequent psychological empowerment, which in turn predicted protean career attitudes and career commitment, but only career commitment had a significant relationship with career satisfaction. Research implications - Empowering leadership behaviors focus on potentially careerenhancing factors, including providing followers with the confidence, inspiration, and authority to assume control of their work lives. Empowering leaders benefit their followers' careers, and psychological empowerment and career commitment may be important mechanisms in the empowering leadership-career success relationship when their effects are considered simultaneously. Employees' development of a protean career orientation has less direct effect on subjective career success than simple commitment to a career.

Originality/value - Empowering leadership has been overlooked in career literature. The findings advance the understanding of how empowering leader behaviors could help employees' subjective career success in a serial mediation model. Additionally, the study empirically 
demonstrates that psychologically empowered employees are more likely to engage in protean career actions and navigate their own career goals.

Keywords Empowering leadership, Psychological empowerment, Protean career orientation, Career commitment, Career satisfaction 


\section{Directing our own careers, but getting help from empowering leaders}

In competitive working environments with decreased job stability, individuals take responsibility for their own careers. Organizations sometimes encourage employees to proactively manage their careers by seeking training, mentorship, and challenging assignments (Arthur, Khapova, \& Wilderom, 2005; Kraimer, Seibert, Wayne, Liden, \& Bravo, 2011). Recent studies show that leaders can influence employees' career outcomes (Kraimer, Seibert, \& Astrove, 2015; Raghuram, Gajendran, Liu, \& Somaya, 2016; Vincent-Höper, Muser, \& Janneck, 2012). For example, transformational leaders positively influenced followers' subjective occupational success via work engagement (Vincent-Höper et al., 2012) or psychological empowerment (Joo \& Lim, 2013). Leader-member exchange (LMX) was related to both intrinsic and extrinsic career success (Kraimer et al., 2015) as well as career benefits on the external job market (Raghuram et al., 2016). Surprisingly, however, little research has discussed how empowering leadership style could affect employees' career outcomes.

In the previous studies, empowering leadership was mainly linked to some specific organizational outcomes including creativity, work effort, job performance, citizenship behaviors, and turnover intentions (Amundsen \& Martinsen, 2015; Chen, Sharma, Edinger, Shapiro, \& Farh, 2011; Fong \& Snape, 2015; Zhang \& Zhou, 2014). We propose, however, that empowering leadership also can help lead to employees' subjective career success (i.e., career satisfaction; Greenhaus, Parasuraman, \& Wormley, 1990). Thus, the criteria for the present study are about individuals' careers rather than specific jobs or organizational effectiveness, and therefore are more directly important for the individual than for the organization.

There are other forms of positive leadership that can be related to career success. Two of the most well-known are transformational leadership and LMX. Conceptually, transformational 
leaders provide a vision for the future and exhibit four kinds of behaviors: idealized influence, intellectual stimulation, inspirational motivation, and individualized consideration. However, these are not clearly part of the empowering leadership, and in fact, transformational leaders may display the four behaviors without transferring power to followers and therefore they do not allow participating in making the vision (Amundsen \& Martinsen, 2014; Sharma \& Kirkman, 2015). Moreover, empirically, empowering leadership was found to be empirically distinct from transformational leadership through confirmatory factor analyses (Pearce, Sims, Cox, Ball, Schnell, Smith, \& Trevino, 2003). LMX means that managers have a unique quality of relationship with each of their followers, rather than having the same relationship across all followers. LMX and empowering leadership are different, because some followers may perceive high quality of the exchange relationship when leaders exhibit directive behaviors and assign goals or work without power sharing (Pearce et al., 2003; Sharma \& Kirkman, 2015). Overall, empowering leadership is a type of leadership that is distinct from other positive leadership styles, and its behaviors in relation to careers have understudied. Thus, there is a need to determine whether empowering leader behaviors can favorably influence employees' career outcomes.

Empowering leadership focuses on potentially career-enhancing factors such as providing individual employees with the confidence, ability, inspiration, and authority to assume control of their work (Ahearne, Mathieu, \& Rapp, 2005). Empowering leadership and employees' subsequent psychological experience of empowerment provide employees the opportunity to develop and become committed to their careers, increasing the likelihood that they will find their careers satisfying. Figure 1 illustrates the proposed process through which this occurs; empowerment theory views psychological empowerment as a mechanism through which 
contextual factors, such as leadership, influence employee responses (Maynard, Gilson \& Mathieu, 2012; Seibert et al., 2011). Hence, psychological empowerment is the first intervening component in the empowering leadership-career success relationship. Additionally, career satisfaction may be influenced by the individual's motivation and career attitudes. Employees feeling psychological empowerment are more likely to pursue work-related goals (career commitment) and professional development according to their internal subjective criteria (protean career orientation) because they believe they are capable of developing a career, which may enhance their experienced career satisfaction/success. Therefore, we posit protean career orientation and career commitment as secondary intervening components linking empowering leadership with subjective career success.

The present study is valuable from both theoretical and practical perspectives: We (1) theoretically contribute by integrating elements of the leadership, empowerment, and career literatures; and (2) provide information for individuals, as well as for consultants and organizations that are increasingly developing programs to facilitate employees' efforts to manage their own careers. Empowering leadership includes power sharing, motivating, and providing development opportunities (Amundsen \& Martinsen, 2014). In response to these leadership behaviors, followers may develop a feeling of psychological empowerment consisting of four cognitions: meaning, competence, self-determination, and impact (Spreitzer, 1995). Meaning comes from a fit between the job and an individual's values. Competence refers to selfefficacy, the belief that one possesses the skills to perform successfully. Self-determination is a sense of control over one's work. Finally, impact represents the belief that one can influence organizational outcomes (Spreitzer, 1995). These four cognitive elements of empowerment 
represent the construct of psychological empowerment and reflect a proactive orientation to one's work role (Spreitzer, 1995; Thomas \& Velthouse, 1990).

Overall, the concept of empowerment is the key to the model. As Seibert, Wang, and Courtright (2011) explain, the employee empowerment construct has two theoretical roots: theories about the intrinsically motivating work environmental variables of job design (especially job autonomy; Hackman \& Oldham, 1980), and individual difference theories about the person's self-efficacy (Bandura, 1986). These two theoretical sources come into play at different points in the present model. The self-efficacy root of empowerment is in the present model's psychological empowerment construct, because it represents the individual's belief in their own ability to control and perform in their environment. The environmental root of empowerment is exhibited in the empowering leadership construct, because the leader is part of the person's environment.

Both the environmental and individual roots include the overarching concept of control, which is key to the model. Note that supervisors, as representatives of the organization, may empower employees with the expectation that the employees will become more committed to the organization. Once the employees feel the psychological state of empowerment on the job, however, it is a short step for the behaviors to generalize that sense of control to work life in general, including to their careers.

The relationship between empowering leadership and psychological empowerment The first link in Figure 1 is between empowering leadership and employees' experience of psychological empowerment. The relationship for empowering leadership with psychological empowerment is likely to be stronger than for other forms of leadership. The behaviors of empowering leaders are aimed at making employees be and feel empowered. Empowering 
leaders also serve as role models for their followers. Followers can learn how to perform their task successfully by observing their leaders and can be encouraged with the leader's verbal persuasion through coaching and feedback. Some previous studies have already supported the first link in the model (e.g., Amundsen \& Martinsen, 2015; Raub \& Robert, 2010).

H1. Empowering leadership is positively related to psychological empowerment.

The relationships of psychological empowerment with protean career orientation and career commitment

In Figure 1, psychological empowerment is expected to be related to protean career orientation and career commitment. The protean career is "a career in which the person is (1) values-driven in the sense that the person's internal values provide the guidance and measure of success for the individual's career; and (2) self-directed in personal career management - having the ability to be adaptive in terms of performance and learning demands" (Briscoe \& Hall, 2006, p. 8). Protean careers are managed by the employees themselves (Arthur et al., 2005). Although little research has directly examined the relationship between psychological empowerment and protean career orientation, it is likely that individuals with a high sense of empowerment would manage their work, including their careers, in self-directed and values-driven ways.

King (2004) argued that career self-management could be influenced by self-efficacy and desire for control, which are related to intrinsic motivation. Empowerment results in more confident employees (Spreitzer, 1995). Based on empowerment theory, Thomas and Velthouse (1990) suggested that individuals can take charge of altering their environmental situations due to empowerment, consistent with the concept of a protean career. They also argued that the 
intrinsic motivation triggered by the positive experiences employees get from their work strengthens their self-management efforts.

Psychologically empowered employees thus feel self-efficacious, and previous research suggested self-efficacy influences the extent to which individuals engage in career selfmanagement and career development activities (Ballout, 2009; King, 2004; Noe \& Wilk, 1993). Therefore, employees who perceive that they are competent are likely to navigate their own career roles according to their personal values to attain desired career outcomes, which is a protean career orientation.

Regarding the link between psychological empowerment and protean careers, therefore, our thinking is as follows. Protean careers are the epitome of self-directed careers. The first writer to notice protean careers is often considered to be Hall (1976), who noted the protean career is self-directed (and therefore autonomous) and aimed at self-fulfillment (and therefore driven by one's own values). This fits well with the study's overarching theme of empowerment in controlling one's own work life. Regarding the specific link in the model from psychological empowerment to protean career orientation, therefore, when people feel psychologically empowered, they can use empowerment's tendency toward self-direction in their careers if they choose; thus the self-direction of protean careers can be an expression of psychological empowerment.

H2a. Psychological empowerment is positively related to protean career orientation.

The model also proposes that employees who perceive themselves as empowered are more likely to be committed to their careers. Career commitment represents the degree to which individuals are motivated to work and remain in a chosen career field or role (Hall, 1971) and 
consists of career planning, identity, and resilience (Carson \& Bedeian, 1994; London, 1983). Career planning includes setting career goals/strategies and developmental needs. Career identity refers to the degree to which individuals define themselves in terms of their line of work. Career resilience represents persistence in the face of career disruption or changing work environments (Carson \& Bedeian, 1994).

As noted earlier, an overall key to the model in Figure 1 is empowerment allowing people to take charge of their careers; theories about the employee's self-efficacy and personenvironment fit (e.g., Verquer, Beehr, \& Wagner, 2003) help explain why psychological empowerment is related to career commitment. If employees can achieve high levels of selfefficacy (in this study through feeling empowerment), they will perceive that they have more influence on many parts of their lives (i.e., generalized self-efficacy), including their careers. Indeed, Öncel (2014) has already shown that generalized self-efficacy is strongly related to people's career adaptability, which can result in a better-fitting career and therefore stronger career commitment. According to London's (1983) model of career motivation, career resilience, a term often used interchangeably with career commitment, is influenced by situational elements such as encouragement of autonomy, opportunities to demonstrate achievement, and opportunities for individual control and discretion, which are all conceptually part of empowerment. Because of empowered employees' sense of control and discretion in their work, they are willing to be involved in the goal planning process to further enhance fit between themselves and their career. Fit is related to employees' organizational commitment (metaanalysis by Verquer et al. 2003), and we expect that it will also be related to career commitment. If employees view themselves as being successful in their chosen field, they are more likely to become increasingly committed to that field, as well as to identify with their career role. 
EMPOWERING LEADERSHIP PREDICTING EMPLOYEE CAREERS 11

$H 2 b$. Psychological empowerment is positively related to career commitment.

The relationships of protean career orientation and career commitment with subjective career success

The construct of career success can be separated into objective and subjective success. Objective success components (e.g., salary and promotion) involve career achievements observable by others. Subjective success components (e.g., career satisfaction), the focus of the present study (see Figure 1), include evaluations by the individual regarding his or her career progress (Judge, Cable, Boudreau, \& Bretz, 1995; Ng, Eby, Sorensen, \& Feldman, 2005). Many studies showed positive relations between objective career success and subjective career success, especially represented by career satisfaction (Judge et al., 1995; Raabe, Frese, \& Beehr, 2007). However, income and promotions as central indicators of objective career success have been criticized because these indicators are dependent on employment context, including organizations, occupational sector, and labor-market conditions (Abele, Spurk, \& Volmer, 2011). Subjective components of career success such as career satisfaction are less affected by these factors (De Vos \& Soens, 2008; Hall, 2002). Moreover, individuals' career accomplishments may have more meaning to and impact on the employees' own evaluations of their careers. Therefore, the present study focuses on subjective career success and operationalizes career success in terms of career satisfaction - individuals' subjective feelings of accomplishment and satisfaction with their careers (e.g., career-related roles and progress) based on their accumulated experiences over their work life (Greenhaus et al., 1990).

Employees having protean career attitudes are expected to feel psychological success with respect to their career progress because they are motivated to plan and pursue meaningful 
career goals based on their own values (Direnzo, Greenhaus, \& Weer, 2015; Hall, 2002). That is, the more autonomy and responsibility employees have, the greater is the likelihood that they will experience psychological success if they attain their goals. Further, psychological success will increase when individuals have experienced success by their own internal standards (not necessarily by those of their organization). There is some related empirical evidence supporting a positive link between protean career orientation and subjective career success. For instance, a positive relationship of some self-directed attitudes (similar to one element of protean career attitudes) with career satisfaction has been found (De Vos \& Soens, 2008; Zhang, Hirschi, Herrmann, Wei, \& Zhang, 2015). In addition, protean career attitude appeared to be an antecedent of career satisfaction and behaviors beyond effects of individual difference dispositions such as core self-evaluations, indicating that a protean career attitude could be an important determinant of subjective career outcomes (Herrmann, Hirschi, \& Baruch, 2015).

Regarding the other element of the protean career attitude, the values-driven attitude, fewer previous research findings are available. However, theoretical considerations support a positive link between a values-driven career attitude and subjective career success, assuming that a values-driven career attitude makes employees guide their careers according to their basic priorities rather than by expectations of others (e.g., the organization) in order to achieve good fit and thereby career success. The values-driven part of protean career orientation means that employees strive to achieve or implement their values through their careers. This happens in two ways: at career choice points (e.g., when choosing or changing careers) and while engaged in career work. When choosing an initial career, or when choosing to change careers, protean career-oriented people opt for careers in which the work will be more consistent with their own values, similar to attraction-selection-attrition theory (Schneider, 1987). Therefore, the values- 
driven part of protean career orientation helps to result in good person-environment fit through career choice; good fit is known to result in favorable outcomes such as positive work attitudes (e.g., meta-analyses by Kristof-Brown, Zimmerman, \& Johnson, 2005; Verquer et al., 2003). In addition, while engaged in a career, the values-driven part of protean career orientation acts as intrinsic motivation. High performance in work that is consistent with one's own values results in feelings of satisfaction, which in turn motivates more hard work in order to achieve that feeling of satisfaction again. The good performance in one's career that comes from this valuesdriven form of intrinsic motivation, thus, results in career satisfaction.

$H 3 a$. Protean career orientation is positively related to subjective career success.

Employees feeling commitment to their careers are also likely to have positive feelings for their progress and accomplishments toward meeting career goals. Career commitment consists of career identification, planning, and resilience. More committed individuals will likely make significant investments in their careers by actively engaging in career planning and trying to acquire new knowledge and skills as part of planning for their career advancement. Moreover, employees who are committed to their career will likely set high career goals for themselves and put more effort and persistence toward being successful in their line of work. They are resilient and therefore able to overcome setbacks with their persistence. These actions lead to higher performance and subsequently contribute to intrinsic rewards such as self-satisfaction (Bandura, 1986) so that they can identify with their careers and become satisfied with them. In fact, occupational commitment was positively related to career satisfaction in a meta-analytic study (Lee, Carswell, \& Allen, 2000). Lastly, career planning (which is more likely to occur with 
committed employees) contributed to increasing employees' career satisfaction (Aryee \& Debrah, 1993).

$H 3 b$. Career commitment is positively related to subjective career success.

The mediated relationship between empowering leadership and subjective career success Although there are a number of studies on empowering leadership, little research has focused on its relation with followers' perception of career success. Hall (1971) suggested psychological success might be related to the amount of challenge and autonomy in the job, job characteristics that are conceptually similar to the empowering leadership. Challenge is important in setting difficult but attainable goals, and self-set goals are encouraged by empowering leadership. Autonomy enables individuals to choose goals relevant to their own career role, which should result in career satisfaction. Because empowering behaviors of a leader allow followers to perform their work more autonomously, they can control more of their careers in terms of goal setting and career plans. Inherent in the model in Figure 1, however, the relationship between empowering leadership and subjective career success is expected to exist because of the mediating effects of the other variables in the model. One prior study indicated that empowered employees showed higher career satisfaction (Joo \& Lim, 2013).

H4. Empowering leadership is positively related to subjective career success, mediated by psychological empowerment, protean career orientation, and career commitment.

\section{Method}

\section{Participants and procedure}

Data were collected at three time points over six weeks in order to reduce the effects of common method bias (Podsakoff, MacKenzie, \& Podsakoff, 2012) and to measure the variables in a 
sequence matching the proposed causal model in Figure 1. Participants were recruited through Amazon's Mechanical Turk, an online research firm that pays respondents for participating in surveys and that provides research participants from a broad range of jobs, people, and geographic locations (Paolacci \& Chandler, 2014). It provides as reliable data as traditional data collection methods, including community-based research and undergraduate students samples (Buhrmester, Kwang, \& Gosling, 2011; Goodman, Cryder, \& Cheema, 2013; Ramsey, Thompson, McKenzie, \& Rosenbaum, 2016). We required respondents to be full-time employed adults aged 18 and older working in the USA. Across the three surveys, qualified respondents received informed consent and could exit the survey at any time without penalty. To match the three surveys, we asked participants to create their own six-digit code number in the first survey and to enter the same code in the second and third surveys. Participants who completed each survey were given a monetary incentive ( $\$ .40$ for Time 1 and Time 2 , and $\$ 1.00$ for Time 3). Initially, 606 employees completed the first survey. Of these, 316 completed the second survey three weeks later, and 288 completed the third survey three weeks after the second survey (47.5\% retention rate from the initial sample). Among them, 27 responses were dropped due to unmatched codes across time points. In addition, to ensure high-quality data, only employees with at least a 95\% approval rating from previous Mturk assignments were solicited, consistent with common recommendations (e.g., Mason \& Suri, 2012), and some participants' data were eliminated due to suspected low effort responding (e.g., above $80 \%$ of the same answers for scales, or, at the first two time periods, completion of the questionnaire in less than half of the average time). Therefore, the hypotheses were tested with 261 responses. The sample consisted of $56.9 \%$ females and $83 \%$ whites, and $60.8 \%$ participants were in the age range from 18 to 39 . 
They were employed in a variety of industries (e.g., retail, technology, and education), and 65.7 $\%$ had at least a bachelor's degree.

To assess whether the final sample (Time 3) was representative of the Time 1 and Time 2 samples, we compared demographic differences among three samples. We found no big differences with respect to demographic variables (age, gender, and education) assessed at Time 1, Time 2, and Time 3; age of the participants increased a little bit across the three survey samples. Also, the percentage who had a bachelor's or higher degree increased from $61.8 \%$ to $65.7 \%$. The gender ratio was almost the identical. Overall, although there was attrition in our samples across the three surveys, no significant differences were found among them. Therefore, it does not seem that there exist any severe systematic sample biases.

\section{Measures}

The first survey (Time 1) measured the predictor variable, empowering leadership, and demographics; the second survey (Time 2) measured the first intervening variable, psychological empowerment; and the third survey (Time 3) measured the career-related three variables. Personality traits used as controls were also measured at the final survey (Time 3).

Empowering leadership was measured using the 18-item Empowering Leadership Scale (Amundsen $\&$ Martinsen, 2014). Four items $(\alpha=.88)$ represent power sharing, six items $(\alpha=$ .93) represent development support, and eight items $(\alpha=.90)$ represent motivational support. An example item is "My leader gives me authority over issues within my department" rated on a 7point Likert scale from 1 (strongly disagree) to 7 (strongly agree). The three subscales were highly correlated with each other, ranging from $r=.72$ to $r=.80$. Reliability for the full scale was .96 . 
Psychological empowerment was assessed with the 12-item Empowerment Scale from Spreitzer (1995), which reflects the four dimensions of psychological empowerment. Three items comprised each subscale: meaning ( $\alpha=.97)$, competence $(\alpha=.90)$, self-determination $(\alpha=.95)$, and impact $(\alpha=.90)$. An example item is "I have considerable opportunity for independence and freedom in how I do my job" rated on a 7-point Likert scale from 1 (strongly disagree) to 7 (strongly agree). The four subscales were at least moderately related to each other $(r=.34$ to $r=$ .61 ), and reliability for the overall scale was .92 .

Protean career orientation was measured with the 14-item Protean Career Attitudes Scale (Briscoe, Hall, \& DeMuth, 2006), which tapped self-direction attitude ( 8 items; $\alpha=.87$ ) and values-driven attitude ( 6 items; $\alpha=.82$ ). An example item is "I am responsible for my success or failure in my career.” Respondents were asked to indicate what extent they considered themselves as the primary person responsible for managing their career on a 5-point Likert scale from 1 (to little or no extent) to 5 (to a very great extent). Reliability for overall scale was .89 .

Career commitment was measured using the 12-item scale from Carson and Bedeian (1994), which consists of the three subscales: career identity ( 4 items; $\alpha=.93$ ), career planning ( 4 items; $\alpha=.90)$, and career resilience ( 4 items; $\alpha=.94)$. An example item is "My line of work/career field is an important part of who I am" rated on a 5-point Likert scale from 1 (strongly disagree) to 5 (strongly agree). Reliability for the overall scale was .89 .

Career satisfaction was measured with five items $(\alpha=.91)$ from Greenhaus et al. (1990). An example item is "I am satisfied with the progress I have made toward meeting my overall career goals" rated on a 5-point Likert scale from 1 (very dissatisfied) to 5 (very satisfied).

Control variables included a variety of demographic variables as well as three personality traits - proactive personality, need for achievement, and learning goal orientation- 
because they have been found to be related to career success (Godshalk \& Sosik, 2003; Ng \& Feldman, 2014; Seibert, Crant, \& Kraimer, 1999). The personality traits were measured using a 7-point Likert scale from 1 (strongly disagree) to 7 (strongly agree). Proactive personality was measured with ten items $(\alpha=.93)$ from Seibert, Kraimer, and Liden (2001) that is a shortened version of Bateman and Crant's (1993) 17-item Proactive Personality Scale. An example item is "I am constantly on the lookout for new ways to improve my life." Need for achievement was assessed using nine items $(\alpha=.92)$ from Eisenberger, Jones, Stinglhamber, Shanock, and Randall (2005). An example item is "I am pleased when I can take on added job responsibilities." Learning goal orientation was measured using Brett and VandeWalle's (1999) five items $(\alpha=.92)$. An example item is "I enjoy challenging and difficult tasks at work where I'll learn new skills.” In a study by Zargar, Vandenberghe, Marchand, and Ayed (2014), proactive personality, need for achievement, and learning goal orientation were investigated to see whether they could represent the single construct of growth need strength. The results of a pilot study and confirmatory factor analysis provided construct validity evidence for a growth need strength construct consisting of these three traits.

Furthermore, because the three personality variables were highly correlated, ranging from $r=.65$ to $r=.85$ in the present study, and prior research indicated that proactive personality was closely related to need for achievement (Bateman \& Crant, 1993) and learning goal orientation (Fuller \& Marler, 2009), we conducted a CFA to see if they loaded on a single factor. The second-order model produced a satisfactory fit, $\chi^{2}(249, N=261)=829.51, p<.01$, RMSEA $=.09, \mathrm{CFI}=.97, \mathrm{NNFI}=.97, \mathrm{IFI}=.97$. Loadings of the first-order factors on higherorder growth need strength factor were as follows: .72 for proactive personality, .98 for need for achievement, and .94 for learning goal orientation. Therefore, we used the single construct of 
growth need strength, representing the three personality traits, as a control variable. Means, standard deviations, internal consistency reliabilities, and correlations of all the variables are in Table 1.

\section{Results}

Structural equation modeling was used to test the hypotheses simultaneously and verify the indirect effect of empowering leadership on career outcomes. For the full SEM with latent variables, subscales were used as manifest indicators of the three measures that had three subscales each (empowering leadership, career commitment, and growth need strength). Similarly, for psychological empowerment, four subscales served as indicators. Career orientation had only two subscales, and the item-parceling method was used to create four indicators. The 14-item measure of protean career orientation was parceled (two parcels consisting of four items for self-direction attitude and two parcels consisting of three items for values-driven attitude). Because career satisfaction is a unidimensional construct without subscales, its five items served as indicators. The measurement model fit, $\chi^{2}(194, N=261)=$ $630.39, p<.01, \mathrm{CFI}=.95, \mathrm{IFI}=.95, \mathrm{NNFI}=.94$, and $\mathrm{RMSEA}=.09$, was satisfactory.

The hypothesized model in Figure 1 also fit the data adequately, but with a somewhat high $\mathrm{RMSEA}, \chi^{2}(203, N=261)=746.04, p<.01, \mathrm{RMSEA}=.10, \mathrm{CFI}=.93, \mathrm{NNFI}=.92, \mathrm{IFI}=$ 93. Standardized parameters are in Figure 2. Empowering leadership was positively related to psychological empowerment $(\beta=.69, p<.01)$, supporting hypothesis 1 . Hypotheses $2 \mathrm{a}$ and $2 \mathrm{~b}$ predicting that psychological empowerment would be positively related to career orientation $(\beta$ $=.39, p<.01)$ and career commitment $(\beta=.85, p<.01)$, were also supported. However, hypothesis 3a was not supported, because the standardized coefficient from protean career 
orientation to career satisfaction was not significant $(\beta=.08, n s)$. The results supported hypothesis $3 \mathrm{~b}$, however, finding that career commitment was positively related to career satisfaction $(\beta=.45, p<.01)$. Overall, consistent with the model, empowering leadership had indirect effects on career satisfaction via the two intervening variables of psychological empowerment and career commitment, supporting the mediation hypothesis 4 .

\section{Control variables}

In addition to the personality variable, growth need strength, we considered controlling for a variety of demographic variables that had been predictors of career variables in past research (Judge et al., 1995). None of demographic variables was significantly associated with the criterion in our model, career satisfaction, but age had a weak correlation with protean career orientation $(r=-.15, p<.05)$. We also found that inclusion of these demographic variables did not change our results. Thus, we did not include and report demographic variables in the model and results section, consistent with existing recommendations (e.g., Bernerth \& Aguinis, 2016; Carlson \& Wu, 2012; Spector \& Brannick, 2011).

However, we included growth need strength as a control variable in testing the model in Figure 2. Growth need strength served two functions as a control variable: (1) methodologically, it was a self-reported psychological variable and therefore controlled for common method effects, and (2) conceptually, it controlled for the effect of a psychological trait that had been found related to career variables. In the present study, it was moderately correlated with the criterion, career satisfaction $(r=.43, p<.01)$. The path from growth need strength to career satisfaction in the diagram was not significant $(\beta=.11, n s)$, however, and the conclusions in the present study did not change after controlling for growth need strength.

Mediation effects 
Mediation effects are embedded in the proposed model, and to further confirm the mediation effects in a different way, bootstrapping analyses on 10,000 samples were performed using the PROCESS macro (Hayes, 2013). Psychological empowerment significantly mediated the relationship between empowering leadership and career commitment $(a b=.16, \mathrm{CI}(95 \%)$ : LL $=$ $\left..10, \mathrm{UL}=.23, k^{2}=.22\right)$. Career commitment was also found to be a significant mediator of the relationship between psychological empowerment and career satisfaction $(a b=.18, \mathrm{CI}(95 \%)$ : $\left.\mathrm{LL}=.11, \mathrm{UL}=.25, k^{2}=.20\right)$. The magnitude of both effect sizes $\left(k^{2}\right)$ can be interpreted as medium with reference to Cohen's standard (Preacher \& Kelley, 2011). We did not test the mediating effect of protean career orientation in the relationship of psychological empowerment with career satisfaction because the path from career orientation to career satisfaction in the diagram (Figure 2) was not significant.

\section{Alternative model}

In addition to testing hypotheses with a single overall model and bootstrapping, an alternative model was tested in which four paths were added, one from empowering leadership to career satisfaction, two from empowering leadership to career orientation and to career commitment, and one from psychological empowerment to the career satisfaction in the model. If there were full mediation in each part of the model, the fit would not improve with the addition of these new direct paths. The alternative model did not improve fit significantly, $\Delta \chi^{2}(4, N=261)=5.97, p=$ .20. The two direct paths from empowering leadership to protean career orientation and to career commitment were not significant, consistent with the principle of psychological empowerment as a mediator. Psychological empowerment also had no direct effect on career satisfaction, indicating that career commitment was indeed an important mediator between them. However, empowering leadership had a direct effect on career satisfaction $(\beta=.18, p<.01)$. This means 
that in addition to the indirect effects, empowering leadership also may have a direct effect on subjective career success. Overall, both the fit statistics for the alternative model and bootstrapping results provide evidence that psychological empowerment in the first part of the model and career commitment in the second part of the model were essential intervening variables linking empowering leadership to the career satisfaction.

\section{Discussion}

The purpose of the present study was to shed light on the potential effects of empowering leadership on employees' career success. Previous research on empowering leadership focused on more job-relevant and organization-relevant criteria instead of on the possible benefits to employees' career progress, which often encompasses multiple jobs and organizations. Results showed that leader empowering behaviors are indeed likely to help employees achieve career success. Empowering leaders are willing to support and provide followers with necessary resources, as well as sharing task-relevant information and expressing high confidence and trust in followers' abilities. Because information and resources have been noted as factors that increase a sense of control and competence at work (Gist \& Mitchell, 1992), leading to a high level of motivation and performance (e.g., Hackman \& Oldham, 1980), followers feel more confident about work roles and future career opportunities within the organization. When empowering leaders assign challenging jobs, provide accurate and clear performance feedback, and encourage discussion of career-related issues, employees also show higher subjective career success. Additionally, empowering leaders contribute to promoting employees' feelings of competence, self-determination, meaningfulness, and impact, which in turn positively affect the development of protean career attitudes and career commitment. That is, employees are more likely to have high levels of career identity, planning, and resilience, as well as manage their 
career self-directedness and value driven ways when they are intrinsically motivated by their increased sense of psychological empowerment.

In contrast to previous studies (e.g., De Vos \& Soens, 2008; Zhang et al., 2015), protean career orientation had no significant unique influence on career satisfaction. This may be due to the fact that individuals with high values on these scales are trying to guide their careers according to their own standards. However, if these values do not fit with the current organization's requirements, a high value-driven career attitude might not be associated with subjective career success. Value misfit between organization and employees leads to negative individual and organizational consequences (Kristof-Brown et al., 2005).

\section{Implications}

Our study supports the importance of empowering leader behaviors and psychological empowerment in predicting subjective career success. Empowerment is an overarching theme in the study, and individuals may especially benefit from what we have learned, because psychologically empowered individuals have the ability to influence and direct their careers through their own decision-making. To whatever extent the leader empowers employees or even simply allows them some discretion, employees feeling empowered can direct their own careers. They can do this by, for example, increasingly developing their skills through formal (e.g., taking advantage of any training offered) and informal (e.g., learning by stretching their job activities beyond their necessary tasks by helping coworkers on other jobs) means. The results suggest that those employees who become committed to their careers due in part to empowerment are especially likely to experience career success (career satisfaction). 
There are also implications for organizations. In order to enhance career satisfaction, as well as the growth and development of followers, organizations should make efforts to encourage managers to engage in empowering behaviors such as promoting participation in decision-making processes, giving greater authority and autonomy, sharing information, and providing development support through coaching and modeling. If such efforts are made, employees will develop favorable career attitudes and actively manage their career paths, which will positively affect their sense of career success. Additionally, if employees feel committed to their career, they are more satisfied with their work life and career progress, and this career satisfaction might contribute to improving overall organizational effectiveness as well as employees' well-being.

Successful careers may not entail staying in the same organization, and therefore empowering leaders could be helping followers develop skills and desires that lead them to leave the organization. An organization's career development efforts (e.g., Raabe et al., 2007) can even include employees' making plans for careers both inside and outside of their present organization, and therefore one may wonder if such programs are beneficial enough for the organization of the current employee to justify the effort and cost. This is a question that has not been answered by past research. Empowering leadership as a contributor to career success, however, not only benefits the employees' career success, but it has additional benefits for the organization, including better performance and citizenship behaviors (Fong \& Snape, 2015; Lorinkova, Pearsall, \& Sims, 2013).

The study contributes theoretically to the literature on empowering leadership by showing how it can influence more than just the job variables that organizations are typically interested in, for example forms of job performance and turnover (e.g., Amundsen \& Martinsen, 
EMPOWERING LEADERSHIP PREDICTING EMPLOYEE CAREERS 25

2015; Chen et al., 2011; Fong \& Snape, 2015; Zhang \& Zhou, 2014). Previous research on empowering leadership focused on those organizational outcomes but ignored the outcomes that can be salient to the individuals even beyond their current organization, as in career outcomes. The present study corrects this oversight, adding to the leadership literature by showing that empowering leadership is related to individuals' careers and career success through mediating processes. We note that a career is broader than a job or a single organization. Individuals' careers can include movement across organizations, which may be why most leadership theories and studies have given relatively little emphasis to career outcomes; a leader is assumed to want to help followers be successful mainly within the leaders' organization. One previous study examined an organization's program to enhance white-collar workers' career self-management actions and skills however, a process that risks developing employees to enhance their careers even by leaving the organization (Raabe et al., 2007). The present study is not about organizations' intentional, formal career-development programs but is about a leadership style that could have similar effects. It increases our knowledge about how careers are, perhaps unintentionally, also enhanced by styles and practices of organizational leaders.

\section{Limitations and future research}

The present study had some limitations. One is that there is a possibility that common method bias influenced the results. This was minimized in multiple ways, however. First, as noted in the method section, the data for participants who responded with the same answer to many items were eliminated. Second, the variables were measured at three different points in time, which reduces common method effects (Podsakoff et al., 2012). Third, the control variable, growth need strength was also measured by self-report and therefore controlled for self-report method effects, as well as for the growth need trait itself. For most of the psychological variables in the 
study, employees themselves are likely to be the best source of information; only they truly know their amount of psychological empowerment and career outcomes (namely protean career orientation, career commitment, and career satisfaction). Empowering leadership, however, could be observable by others who are present in the workplace. Future research on career success could have coworkers report leaders' behaviors.

The model was supported overall, but one link in the proposed model was not supported: the path from protean career orientation to career satisfaction. This link was nonsignificant in the present study even though previous studies had reported significant relationships between these two variables (e.g., De Vos \& Soens, 2008; Zhang et al., 2015). The protean career requires the employee to assess the job market frequently as well as to predict future job market situations, and then to adjust by, for example, obtaining training for skills to better fit new and anticipated future market situations. Unfortunately, making the job choices too salient, considering too many choices, and doing these comparisons too often may make people less rather than more satisfied. That is, always seriously considering and looking for better alternatives is a path to becoming less satisfied with one's current career situation, theoretically, because one's current job suffers by comparisons to the very best jobs one sees elsewhere. This phenomenon has been observed in many contexts (e.g., consumer comparison shopping), including the context of searching for one's initial job after finishing school (e.g., Iyengar, Wells, \& Schwartz, 2006). This may account for the nonsignificant path from protean career orientation to career satisfaction. We hypothesized a positive relationship based on the protean career approaches of career planning and searching for meaningful work that fits the person's values, but the protean career activity of constantly searching the job market for something better may have a countervailing effect. Aside from protean career orientation itself, maximizers (more than satisficers) tend to actively search 
for better alternatives. Future research could include a measure of satisficing-maximizing tendencies and measures of job search activities in order to test the possible countervailing effects of the different elements of protean career orientation.

Career commitment and protean career orientation are somewhat novel additions to the careers literature on subjective career success. Career commitment was a clear and strong mediator in the present study, a proximal predictor of career satisfaction, mediating the relationship of the more distal predictor of psychological empowerment with career satisfaction. Future research should continue to examine career commitment in order to determine how broad its effects are; in addition to mediating the effects of leadership and empowerment for example, does it also help to explain effects of variables from other work-related domains such as environmental variables like job design and personal variables like a sense of achievement?

A previous study had shown that protean career orientation might lead to career satisfaction, but only through mediators (Cao, Hirschi, \& Deller, 2013). That study however, was with the very specific employment situation of self-initiated expatriates. We should note that study only examined mediation with cross-sectional data, but the conclusion was that cultural adjustment was the mediator through which protean career orientation had its effect. Protean career orientation's relatively weak direct relationship with career satisfaction in the present study $(r=.21, p<.01)$, and its nonsignificant path when combined in the model with other predictors, is consistent with the possibility that protean career orientation may be only a more distal predictor of career satisfaction instead of an immediate predictor. Future research should examine potential mediators between protean career orientation and career satisfaction. Generalizing from Cao et al.'s (2013) study of expatriates, a mediator that resembles adjustment would be a logical choice. Because adjustment usually is characterized by increasing person- 
environment fit, we suggest examining such fit as a mediator between protean career orientation and career satisfaction.

\section{Conclusion}

The present study provides a theoretical contribution by showing integrated relationships among empowering leadership, intrinsic motivation in the form of psychological empowerment, and career-related outcomes with career success in the form of career satisfaction as the ultimate goal. Unlike prior research reporting individual characteristics such as personality (which was controlled in the present study) and experience as determinants of career success, the present study demonstrates that empowering leaders play a critical role in the subjective career success

of their followers and that this relationship is also mediated by psychological empowerment and career commitment. Therefore, organizations can make employees feel psychologically empowered through empowering behaviors of a leader in order to enhance their career commitment, which in turn improves subjective career success. 
EMPOWERING LEADERSHIP PREDICTING EMPLOYEE CAREERS 29

\section{References}

Abele, A. E., Spurk, D. and Volmer, J. (2011), “The construct of career success: measurement issues and an empirical example", Journal for Labor Market Research, Vol. 43 No. 3, pp. 195-206.

Ahearne, M., Mathieu, J. and Rapp, A. (2005), “To empower or not to empower your sales force? An empirical examination of the influence of leadership empowerment behavior on customer satisfaction and performance", Journal of Applied Psychology, Vol. 90 No. 5, pp. $945-955$.

Amundsen, S. and Martinsen, Ø. L. (2014), “Empowering leadership: construct clarification, conceptualization, and validation of a new scale", The Leadership Quarterly, Vol. 25 No. 3, pp. 487-511.

Amundsen, S. and Martinsen, Ø. L. (2015), "Linking empowering leadership to job satisfaction, work effort, and creativity: the role of self-leadership and psychological empowerment", Journal of Leadership \& Organizational Studies, Vol. 22 No. 3, pp. 304-323.

Arthur, M. B., Khapova, S. N. and Wilderom, C. P. (2005), "Career success in a boundaryless career world”, Journal of Organizational Behavior, Vol. 26 No. 2, pp. 177-202.

Aryee, S. and Debrah, Y. A. (1993), “A cross-cultural application of a career planning model”, Journal of Organizational Behavior, Vol. 14 No. 2, pp. 119-127.

Ballout, H. I. (2009), “Career commitment and career success: moderating role of self-efficacy”, Career Development International, Vol. 14 No. 7, pp. 655-670.

Bandura, A. (1986), Social Foundations of Thought and Action: A Social-Cognitive Theory, Prentice-Hall, New York, NY. 
EMPOWERING LEADERSHIP PREDICTING EMPLOYEE CAREERS 30

Bateman, T. S. and Crant, J. M. (1993), "The proactive component of organizational behavior: a measure and correlates", Journal of Organizational Behavior, Vol. 14 No. 2, pp. 103 118.

Bernerth, J. B. and Aguinis, H. (2016), “A critical review and best-practice recommendations for control variable usage", Personnel Psychology, Vol. 69 No. 1, pp. 229-283.

Brett, J. F. and VandeWalle, D. (1999), “Goal orientation and goal content as predictors of performance in a training program", Journal of Applied Psychology, Vol. 84 No. 6, pp. 863-873.

Briscoe, J. P. and Hall, D. T. (2006), “The interplay of boundaryless and protean careers: combinations and implications", Journal of Vocational Behavior, Vol. 69 No. 1, pp. 4-18.

Briscoe, J. P., Hall, D. T. and DeMuth, R. L. F. (2006), "Protean and boundaryless careers: an empirical exploration”, Journal of Vocational Behavior, Vol. 69 No. 1, pp. 30-47.

Buhrmester, M., Kwang, T. and Gosling, S. D. (2011), “Amazon's Mechanical Turk a new source of inexpensive, yet high-quality, data?” Perspectives on Psychological Science, Vol. 6 No. 1, pp. 3-5.

Carson, K. D. and Bedeian, A. G. (1994), "Career commitment: construction of a measure and examination of its psychometric properties", Journal of Vocational Behavior, Vol. 44 No. 3, pp. 237-262.

Carlson, K. D. and Wu, J. (2012), “The illusion of statistical control: control variable practice in management research", Organizational Research Methods, Vol. 15 No. 3, pp. 413-435.

Cao, L., Hirschi, A. and Deller, J. (2013). "The positive effects of a protean career attitude for self-initiated expatriates: cultural adjustment as a mediator", Career Development International, Vol. 18 No. 1, pp. 56-77. 
Chen, G., Sharma, P. N., Edinger, S. K., Shapiro, D. L. and Farh, J. L. (2011), "Motivating and demotivating forces in teams: cross-level influences of empowering leadership and relationship conflict", Journal of Applied Psychology, Vol. 96 No. 3, pp. 541-557.

De Vos, A. and Soens, N. (2008), "Protean attitude and career success: the mediating role of self-management", Journal of Vocational Behavior, Vol. 73 No. 3, pp. 449-456.

Direnzo, M. S., Greenhaus, J. H. and Weer, C. H. (2015), "Relationship between protean career orientation and work-life balance: a resource perspective", Journal of Organizational Behavior, Vol. 36 No. 4, pp. 538-560.

Eisenberger, R., Jones, J. R., Stinglhamber, F., Shanock, L. and Randall, A. T. (2005), “Flow experiences at work: for high need achievers alone?", Journal of Organizational Behavior, Vol. 26 No. 7, pp. 755-775.

Fong, K. H. and Snape, E. (2015), "Empowering leadership, psychological empowerment and employee outcomes: testing a multi-level mediating model”, British Journal of Management, Vol. 26 No. 1, pp. 126-138.

Fuller, B. and Marler, L. E. (2009), “Change driven by nature: a meta-analytic review of the proactive personality literature", Journal of Vocational Behavior, Vol. 75 No. 3, pp. 329345 .

Gist, M. E. and Mitchell, T. R. (1992), "Self-efficacy: a theoretical analysis of its determinants and malleability", Academy of Management Review, Vol. 17 No. 2, pp. 183-211.

Godshalk, V. M. and Sosik, J. J. (2003), “Aiming for career success: the role of learning goal orientation in mentoring relationships", Journal of Vocational Behavior, Vol. 63 No. 3, pp. 417-437. 
Goodman, J. K., Cryder, C. E. and Cheema, A. (2013), "Data collection in a flat world: the strengths and weaknesses of Mechanical Turk samples", Journal of Behavioral Decision Making, Vol. 26 No. 3, pp. 213-224.

Greenhaus, J. H., Parasuraman, S. and Wormley, W. M. (1990), “Effects of race on organizational experiences, job performance evaluations, and career outcomes”, Academy of Management Journal, Vol. 33 No. 1, pp. 64-86.

Hackman, J. R. and Oldham, G. R. (1980), Work Redesign. Addison-Wesley, Reading MA.

Hall, D. T. (1971), “A theoretical model of career subidentity development in organizational settings", Organizational Behavior and Human Performance, Vol. 6 No. 1, pp. 50-76.

Hall, D. T. (1976). Careers in Organizations, Glenview, IL: Scott, Foresman.

Hall, D. T. (2002), Careers In and Out of Organizations, Sage Publications, Thousand Oaks, CA.

Hayes, A. F. (2013), Introduction to Mediation, Moderation, and Conditional Process Analysis: A Regression-Based Approach, The Guilford Press, New York, NY.

Herrmann, A., Hirschi, A. and Baruch, Y. (2015), “The protean career orientation as predictor of career outcomes: evaluation of incremental validity and mediation effects", Journal of Vocational Behavior, Vol. 88, pp. 205-214.

Iyengar, S. S., Wells, R. E. and Schwartz, B. (2006), "Doing better but feeling worse: looking for the "best" job undermines satisfaction", Psychological Science, Vol. 17 No. 2, pp.143150.

Joo, B. K. and Lim, T. (2013), "Transformational leadership and career satisfaction: the mediating role of psychological empowerment”, Journal of Leadership \& Organizational Studies, Vol. 20 No. 3, pp. 316-326. 
Judge, T. A., Cable, D. M., Boudreau, J. W. and Bretz, R. D. (1995), “An empirical investigation of the predictors of executive career success", Personnel Psychology, Vol. 48 No. 3, pp. 485-519.

King, Z. (2004), “Career self-management: its nature, causes and consequences”, Journal of Vocational Behavior, Vol. 65 No. 1, pp. 112-133.

Kraimer, M. L., Seibert, S. E. and Astrove, S. L. (2015), “Consequences of high LMX: career mobility and success", In Bauer, T. N. and Erdogan, B. (Eds), The Oxford Handbook of Leader-Member Exchange, Oxford University Press, Oxford, UK, pp. 241-259.

Kraimer, M. L., Seibert, S. E., Wayne, S. J., Liden, R. C. and Bravo, J. (2011), “Antecedents and outcomes of organizational support for development: the critical role of career opportunities", Journal of Applied Psychology, Vol. 96 No. 3, pp. 485-500.

Kristof-Brown, A. L., Zimmerman, R. D. and Johnson, E. C. (2005), “Consequences of individual's fit at work: a meta-analysis of person-job, person-organization, persongroup, and person-supervisor fit”, Personnel Psychology, Vol. 58 No. 2, pp. 281-342.

Lee, K., Carswell, J. J. and Allen, N. J. (2000), “A meta-analytic review of occupational commitment: relations with person-and work-related variables", Journal of Applied Psychology, Vol. 85 No. 5, pp. 799-811.

London, M. (1983), “Toward a theory of career motivation”, Academy of Management Review, Vol. 8 No. 4, pp. 620-630.

Lorinkova, N. M., Pearsall, M. J. and Sims, H. P. (2013), “Examining the differential longitudinal performance of directive versus empowering leadership in teams", Academy of Management Journal, Vol. 56 No. 2, pp. 573-596. 
Mason, W. and Suri, S. (2012), “Conducting behavioral research on Amazon's Mechanical Turk”, Behavioral Research Methods, Vol. 44 No. 1, pp. 1-23.

Maynard, M. T., Gilson, L. L. and Mathieu, J. E. (2012), “Empowerment—fad or fab? A multilevel review of the past two decades of research", Journal of Management, Vol. 38 No. 4, pp. 1231-1281.

Ng, T. W., Eby, L. T., Sorensen, K. L. and Feldman, D. C. (2005), "Predictors of objective and subjective career success: a meta-analysis”, Personnel Psychology, Vol. 58 No. 2, pp. $367-408$.

Ng, T. W. and Feldman, D. C. (2014), "Subjective career success: a meta-analytic review”, Journal of Vocational Behavior, Vol. 85 No. 2, pp. 169-179.

Noe, R. A. and Wilk, S. L. (1993), 'Investigation of the factors that influence employees' participation in development activities", Journal of Applied Psychology, Vol. 78 No. 2, pp. 291-302.

Öncel, L. (2014), “Career Adapt-abilities Scale: convergent validity of subscale scores”, Journal of Vocational Behavior, Vol. 85 No.1, pp. 13-17.

Paolacci, G. and Chandler, J. (2014), “Inside the Turk: understanding Mechanical Turk as a participant pool”, Current Directions in Psychological Science, Vol. 23 No. 3, pp. 184188.

Pearce, C. L., Sims Jr, H. P., Cox, J. F., Ball, G., Schnell, E., Smith, K. A. and Trevino, L. (2003), “Transactors, transformers and beyond: a multi-method development of a theoretical typology of leadership”, Journal of Management Development, Vol. 22 No. 4, pp. 273-307. 
Podsakoff, P. M., MacKenzie, S. P. and Podsakoff, N. P. (2012), "Sources of method bias in social science research and recommendations on how to control it", Annual Review of Psychology, Vol. 63, No. 1, pp. 539-569.

Preacher, K. J. and Kelley, K. (2011), "Effect size measures for mediation models: quantitative strategies for communicating indirect effects", Psychological Methods, Vol. 16 No. 2 , pp. 93-115.

Raabe, B., Frese, M. and Beehr, T. A. (2007), “Action regulation theory and career selfmanagement”, Journal of Vocational Behavior, Vol. 70 No. 2, pp. 297-311.

Raghuram, S., Gajendran, R., Liu, H. and Somaya, D. (2017), “Boundaryless LMX: examining LMX's impact on external career outcomes and alumni goodwill”, Personnel Psychology, Vol. 70, pp. 399-428.

Ramsey, S. R., Thompson, K. L., McKenzie, M. and Rosenbaum, A. (2016), "Psychological research in the internet age: the quality of web-based data", Computers in Human Behavior, Vol. 58, pp. 354-360.

Raub, S. and Robert, C. (2010), "Differential effects of empowering leadership on in-role and extra-role employee behaviors: exploring the role of psychological empowerment and power values", Human Relations, Vol. 63 No. 11, pp. 1743-1770.

Schneider, B. (1987), “The people make the place”, Personnel Psychology, Vol. 40 No. 3, pp. 437-453.

Seibert, S. E., Crant, J. M. and Kraimer, M. L. (1999), "Proactive personality and career success", Journal of Applied Psychology, Vol. 84 No. 3, pp. 416-427.

Seibert, S. E., Kraimer, M. L. and Liden, R. C. (2001), “A social capital theory of career success”, Academy of Management Journal, Vol. 44 No. 2, pp. 219-237. 
Seibert, S. E., Wang, G. and Courtright, S. H. (2011), “Antecedents and consequences of psychological and team empowerment in organizations: a meta-analytic review", Journal of Applied Psychology, Vol. 96 No. 5, pp. 981-1003.

Sharma, P. N. and Kirkman, B. L. (2015), "Leveraging leaders: a literature review and future lines of inquiry for empowering leadership research", Group \& Organization Management, Vol. 40 No. 2, pp. 193-237.

Spector, P. E. and Brannick, M. T. (2011), "Methodological urban legends: the misuse of statistical control variables", Organizational Research Methods, Vol. 14 No. 2, pp. 287305.

Spreitzer, G. M. (1995), "Psychological empowerment in the workplace: dimensions, measurement, and validation", Academy of Management Journal, Vol. 38 No. 5, pp. $1442-1465$.

Tekleab, A. G., Sims Jr, H. P., Yun, S., Tesluk, P. E. and Cox, J. (2008), “Are we on the same page? Effects of self-awareness of empowering and transformational leadership", Journal of Leadership \& Organizational Studies, Vol.14 No. 3, pp. 185-202.

Thomas, K. W. and Velthouse, B. A. (1990), “Cognitive elements of empowerment: an “interpretive" model of intrinsic task motivation", Academy of Management Review, Vol. 15 No. 4, pp. 666-681.

Verquer, M. L., Beehr, T. A. and Wagner, S. H. (2003), “A meta-analysis of relations between person-organization fit and work attitudes”, Journal of Vocational Behavior, Vol. 63 No. 3, pp. 473-489. 
Vincent-Höper, S., Muser, C. and Janneck, M. (2012), “Transformational leadership, work engagement, and occupational success", Career Development International, Vol. 17 No. 7, pp. 663-682.

Zargar, M. S., Vandenberghe, C., Marchand, C. and Ayed, A. K. B. (2014), “Job scope, affective commitment, and turnover: the moderating role of growth need strength", Journal of Occupational and Organizational Psychology, Vol. 87 No. 2, pp. 280-302.

Zhang, C., Hirschi, A., Herrmann, A., Wei, J. and Zhang, J. (2015), "Self-directed career attitude as predictor of career and life satisfaction in Chinese employees: calling as mediator and job insecurity as moderator", Career Development International, Vol. 20 No. 7, pp. 703 716.

Zhang, X. and Zhou, J. (2014), "Empowering leadership, uncertainty avoidance, trust, and employee creativity: interaction effects and a mediating mechanism", Organizational Behavior and Human Decision Processes, Vol. 124 No. 2, pp. 150-164. 
EMPOWERING LEADERSHIP PREDICTING EMPLOYEE CAREERS 38

Table 1.

Means, standard deviations, reliabilities, and correlations of all variables

\begin{tabular}{|c|c|c|c|c|c|c|c|c|c|c|c|}
\hline Variables & Mean & $S D$ & 1 & 2 & 3 & 4 & 5 & 6 & 7 & 8 & 9 \\
\hline 1. Empowering leadership (T1) & 4.93 & 1.12 & .96 & & & & & & & & \\
\hline 2. Psychological empowerment (T2) & 5.41 & 1.02 & $.56^{* *}$ & .92 & & & & & & & \\
\hline 3. Protean career orientation (T3) & 3.49 & .68 & $.26 * *$ & $.23 * *$ & .89 & & & & & & \\
\hline 4. Career commitment (T3) & 3.54 & .78 & $.51 * *$ & $.57 * *$ & $.22 * *$ & .89 & & & & & \\
\hline 5. Career satisfaction (T3) & 3.57 & .82 & $.46^{* *}$ & $.41 * *$ & $.21 * *$ & $.50 * *$ & .91 & & & & \\
\hline 6. Growth need strength (T3) & 5.40 & .93 & $.50 * *$ & $.56^{* *}$ & $.47 * *$ & $.52 * *$ & $.43^{* *}$ & .96 & & & \\
\hline 7. Age & 2.33 & 1.19 & -.01 & .01 & $-.15^{*}$ & -.01 & .01 & -.08 & - & & \\
\hline 8. Gender & 1.57 & .50 & -.03 & .01 & -.03 & .00 & -.04 & .06 & -.06 & - & \\
\hline 9. Education & 1.66 & .48 & -.04 & .30 & .01 & .10 & .06 & .03 & -.00 & -.01 & - \\
\hline
\end{tabular}

Notes: $n=261$. Reliabilities are in italics on the diagonal. Age: 18 to $29=1 ; 30$ to $39=2 ; 40$ to $49=3 ; 50$ to $59=4 ; 60$ or older $=5$. Gender: male $=1$; female $=2$. Education: less than bachelor's degree $=1$; bachelor's degree or above $=2$.

$* * p<.01$.

$* p<.05$. 
Time 1

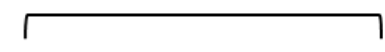

Time 2

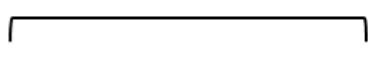

Time 3

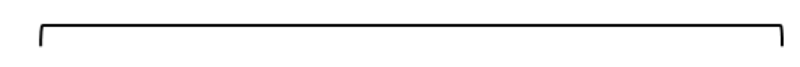

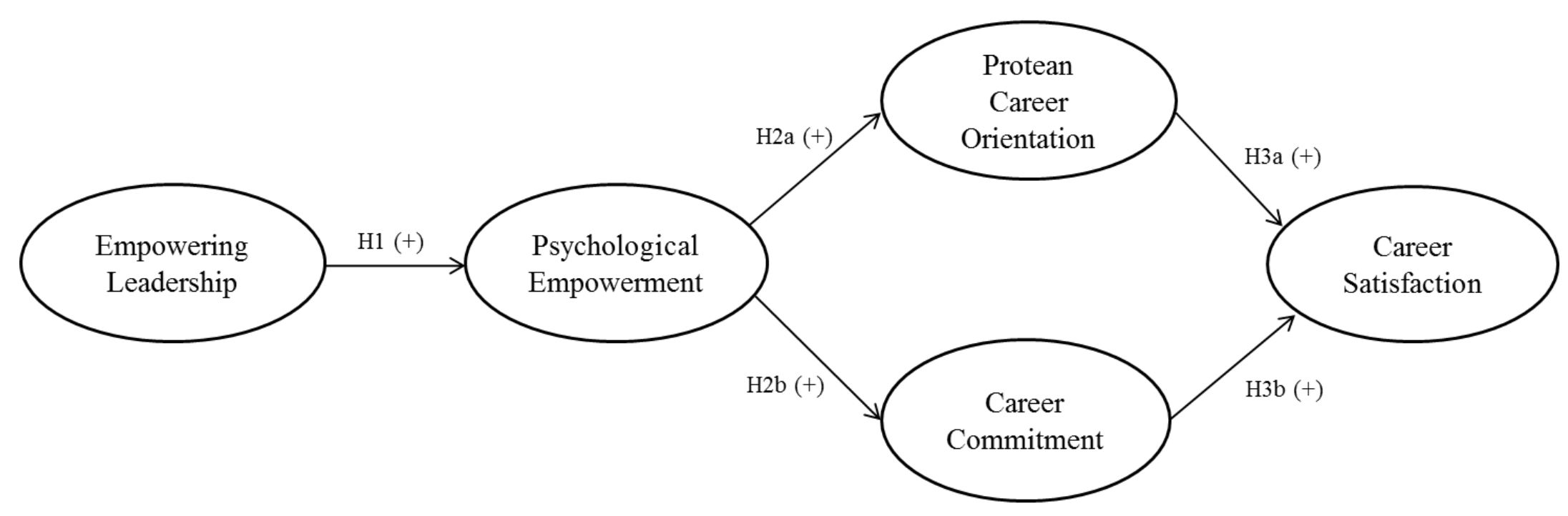

H4: Mediating effect

Figure 1. Hypothesized model 
Time 1
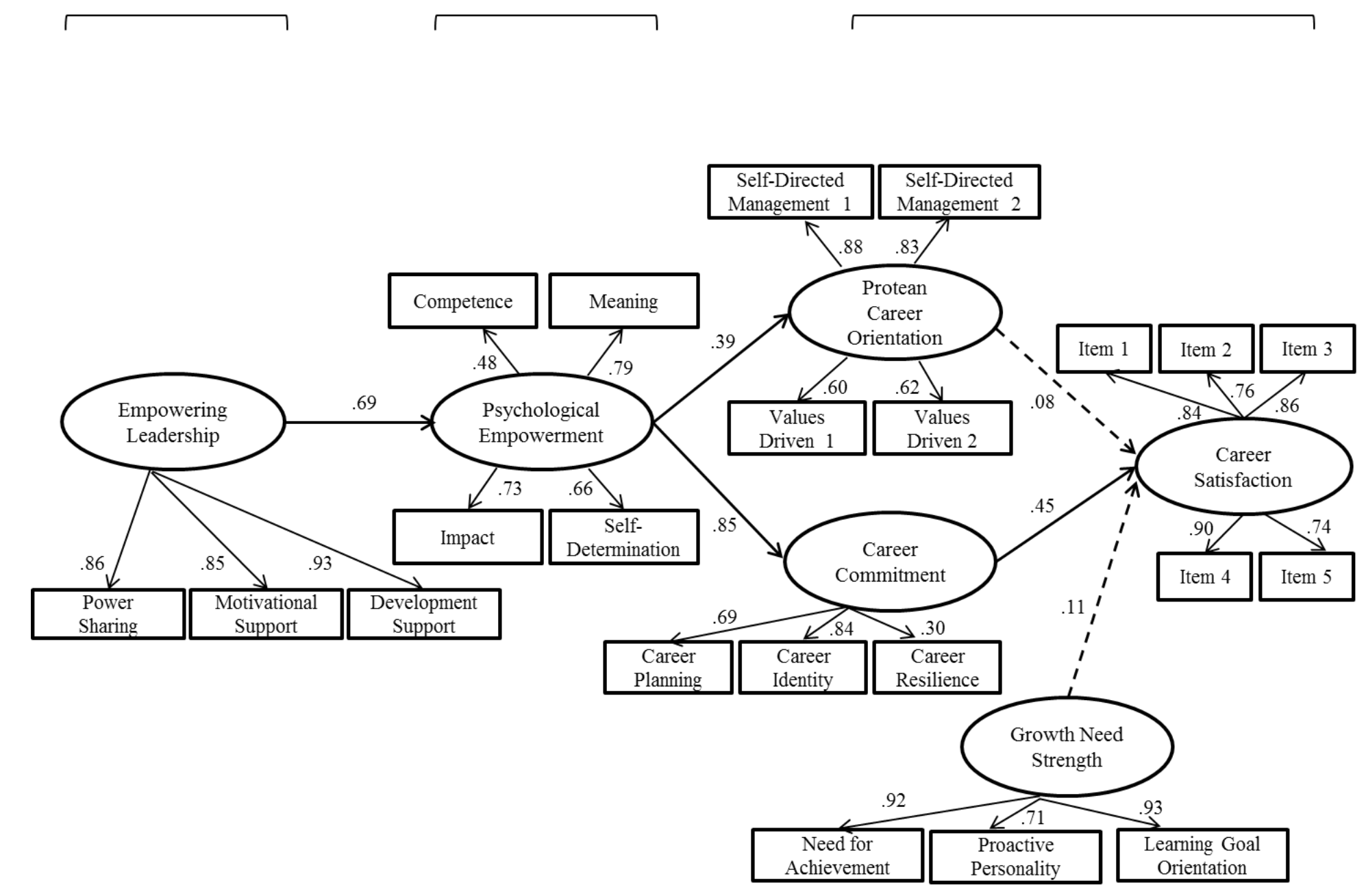

Figure 2. Structural equation model with standardized coefficients
Time 3

Time 2

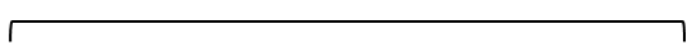

Notes: Broken lines indicate paths that were not significant. All paths in the hypothesized structural model are significant at $p<.01$. 